\title{
Women Managers and the Experience Of Work-Family Conflict
}

\author{
Megan Apperson, Heather Schmidt, \\ Sarah Moore, and Leon Grunberg \\ Comparative Sociology Department \\ University of Puget Sound \\ Tacoma, Washington 98416 USA
}

\author{
Ed Greenberg \\ Department of Political Science \\ University of Colorado \\ Boulder, Colorado 80309-0483 USA
}

Received: July 25, $2002 \quad$ Accepted: October 22, 2002

\begin{abstract}
Gender and managerial status have previously been found to relate to work-family conflict, though the combination of gender and managerial status has received less attention. This study explores differences in levels of work-family conflict and related job attitude and health and coping variables among women managers, men managers, women non-managers, and men non-managers at a large organization. Women managers experienced higher levels of workfamily conflict, work role overload, and problem drinking. However, the levels of work to family conflict were unexpectedly similar between women and men managers. Possible explanations for this are considered.
\end{abstract}

\section{INTRODUCTION}

For the majority of men and women today, parenthood is combined with full-time paid work [1]. Although having multiple roles has been found to be beneficial to over-all wellbeing for both men and women [2,3], multiple roles can also lead to role conflict and negative psychological outcomes [4,5]. These negative outcomes may be a result of time-based conflict, strain-based conflict, or behavior-based conflict [6]. Role conflict exists when performance in one role creates an inability to adequately perform another role [6].

Gender's effect on work-family conflict has been considered in previous studies. Work-family conflict is defined as a type of role conflict in which the pressures of family and work domains are incompatible [7]. While some studies report few differences between men's and women's level of work-family conflict [4], other studies have found that women experience higher levels of work-family conflict than do men [810]. The explanation commonly given for differences in levels of work-family conflict is that women view family as their primary obligation and attach more meaning to their parenting role than to their work role [10]. Managers can be expected to experience higher levels of work-family conflict when compared to non-managers. Factors associated with managerial careers, including long hours and psychologically demanding work, have been demonstrated to correlate with work-family conflict $[4,11]$. Moreover, job involvement, defined as the extent to which a person identifies with their job and the degree of influence the job has on self-image and self-concept [12], has also been found to have a positive relationship with work-family conflict $[2,13]$.

Accompanying women's increased participation in the paid workforce over the past decades has been an increase in the number of women holding management positions. In fact, the number of female 
managers now nearly equals the number of male managers [14]. However, as Reskin and Ross demonstrated, there is a continuing disparity in monetary reward received and authority vested by women managers as compared to men managers [14].

Women managers' work success and involvement does not necessarily rule out the desire to have a family. Despite the fact that female managers are less likely to be married and to have children than their male counterparts [15,16], Blair-Loy [17] found that younger generations of highranking female executives were more likely than older generations to view the role of manager as compatible with the role of mother or wife (2001). Nonetheless, the managerial career often assumes, and even requires for success, full time domestic support, with the most successful managers being those with the most extensive domestic support [15]. Because women managers are less likely to have full time domestic support in the form of a stay-athome spouse, and because they may still bear the primary responsibility for domestic and childcare duties [18], it is reasonable to expect that they might experience higher levels of work-family conflict than their nonmanager and male counterparts.

Using survey data, we investigated the levels of work-family conflict among women managers as compared to men managers, men non-managers, and women non-managers. We hypothesized that women managers would report the highest levels of work-family conflict.

In addition to family issues, we explored differences in health and coping and job attitude among our four groups. We reasoned that higher levels of work-family conflict would be manifested in health problems. Indeed, extensive literature suggests that work family conflict is associated with poor health, problem drinking, and high stress levels $[19,20]$. As discussed previously, job involvement is also positively correlated with work-family conflict [2,13]. Due to the correlation between work-family conflict and these variables, we hypothesize that women managers will report higher levels of health problems and job involvement. In addition, we explored differences between groups on job stress, intent to quit, work overload, and reports of being challenged on the job.

\section{METHODS}

\section{a. Participants}

This study was conducted in a large manufacturing organization located in the western United States. As of 1997 the organization employed approximately 100,000 blue and white-collar employees. Thirty-seven hundred employees, representing all pay codes in the company, were randomly chosen. The chosen employees were then contacted via letter and were assured confidentiality if they chose to participate in the survey. Union support was obtained and a twenty-dollar payment received for participation. Two-thousand two-hundred and seventy-nine usable questionnaires were returned $(62 \%$ response rate). Approximately $24 \%$ (22\%) of the respondents were female. Out of the entire pool of respondents, $14.5 \%(10 \%)$ were salaried- professional and administration employees (actual company percentage are in parentheses). In the final sample, there were 1,463 male nonmanagers, 264 male managers, 475 female non-managers, and 64 female managers.

Participants' marital or relationship status and parenting status, are reported in Table 1.

\section{b. Materials and Procedures}

The data reported in this study are a subset of measures from the first wave of a four-year, longitudinal study that focuses on work change, work attitudes, and health outcomes. Based on extensive reading of literature, preliminary individual interviews, focus groups with current employees, and a pilot test of the survey, a questionnaire was designed to investigate several work-related attitudes, general mental and physical health-related perceptions, work outcomes, alcohol consumption and alcohol problems. Most of the scales found in this study are commonly found measures in the literature; however, some have been modified or developed for the purpose of this study (See Table 2). In our analyses, the $\mathrm{N}$ values varied because some participants did not respond to all questions. 


\begin{tabular}{llcc}
\hline Male & Non-Managers & 48.4 & 77.5 \\
& Managers & 54.2 & 87.5 \\
\hline \multirow{2}{*}{ Female } & Non-Managers & 40.2 & 63.2 \\
& Managers & 37.5 & 78.1 \\
\hline
\end{tabular}

Table 1. Percentages of four groups' marital status and presence of children.

\section{RESULTS}

We conducted a series of 2 (gender) $\times 2$ (managerial status) ANOVAs in order to examine main and interaction effects among four groups. Other variables that normally serve as experimental controls (e.g. marital status, gender, whether or not the participant has children) were used as independent variables in this research. Age and income were entered as covariates in all analyses.

As listed in Table 2, group differences on a variety of dependent variables were examined, focusing on three areas: job attitudes, health and coping, and family issues. The category of job attitudes was investigated using the variables of job stress, intent to quit, work overload, job involvement and job challenge. In the category of health and coping, we used the variables of health problems, problem drinking, mastery and proactive coping behavior. Lastly, with regards to family issues, we utilized the variables of family to work conflict (family interfering with work), work to family conflict (work interfering with family) and a recent shift to family focus (placing more importance on family and leisure than on work). As checks on demographic differences between groups, we also examined the spouse's level of employment (unemployed, part-time or fulltime employed).

\section{b. Main Effect of Managerial Status}

The variables with a significant managerial effect are job stress, job involvement, work overload, job challenge, health problems, work to family conflict, shift to family focus, and spouse employment. All of these variables involving a managerial effect suggest that managers have higher stress levels, $F(1,2113)=36.44, p<.001$, higher levels of job involvement, $F(1,2150)$ $=65.49, p<.001$, higher levels of work overload, $F(1,2179)=67.67, p<.001$, higher levels of challenge on the job, $F(1,2170)=$ $45.49, \mathrm{p}<.001$, report more health problems, $F(1,2107)=4.265, p<.05$, have had a greater shift in emphasis from work to family in the past two years, $F(1,2128)=38.56$, $p<.001$, have higher levels of work to family conflict, $F(1,2187)=47.65, p<.001$, and are less likely to have an employed spouse, $F(1$, $1719)=23.53, p<.001$.

\section{b. The Main Effect of Gender}

The main effect of gender is found for the variables of reports of being overloaded at work, $F(1,2179)=5.44$, $p<.05$, health problems, $F(1,2107)=9.89$, $p<.01$, and whether the spouse is employed, $F(1,1719)=13.00, p<.001$. The main effect of gender shows that women experience more work overload, report more health problems, and are more likely to have spouses or partners who are employed.

\section{c. Managerial Status x Gender Interactions}

We found significant interactions for work overload, problem drinking, work to family conflict, and spouse employment. Women managers (1) report higher levels of being burdened with too much work, $F(1$, $2179)=4.87, p<.05$, (2) report more problems with alcohol, $F(1,1780)=5.15$, 


\begin{tabular}{|c|c|c|c|c|}
\hline Scale & $\begin{array}{c}\text { Number } \\
\text { of } \\
\text { Items }\end{array}$ & $\begin{array}{l}\text { Possible } \\
\text { Range }\end{array}$ & Alpha & Author(s) \\
\hline \multicolumn{5}{|l|}{ Job Attitudes } \\
\hline Job Stress & 6 & $0-18$ & 0.82 & [21] Smith, P., et al. (1992) \\
\hline Intent to Quit & 3 & 3-15 & 0.83 & [22] Cammann, C., et al. (1983) \\
\hline Work Overload & 3 & 3-15 & 0.76 & [22] Cammann, C., et al. (1983) \\
\hline Job Involvement & 8 & 8-39 & 0.70 & [23] Lodahl, T. \& Kejner, M. (1965) \\
\hline Job Challenge & 3 & 3-15 & 0.74 & [22] Cammann, C., et al. (1983) \\
\hline \multicolumn{5}{|l|}{ Health and Coping } \\
\hline Health Problems ${ }^{a}$ & 6 & $0-6$ & NA & [24] Moos, R., et al. (1986) \\
\hline Problem Drinking & 4 & $0-4$ & 0.64 & [25] Ewing, J. (1984) \\
\hline Mastery & 7 & 8-35 & 0.82 & $\begin{array}{l}\text { [26] Pearlin, L.I. \& Schooler, C. } \\
\text { (1978) }\end{array}$ \\
\hline Proactive Coping & 5 & $5-15$ & 0.72 & [27] Amirkhan, J.H. (1990) \\
\hline \multicolumn{5}{|l|}{ Family Issues } \\
\hline \multicolumn{5}{|l|}{ Family to Work } \\
\hline Conflict & 2 & $2-8$ & 0.70 & $\begin{array}{l}\text { [28] Frone, M., Russell, M., \& } \\
\text { Cooper, M. (1992) }\end{array}$ \\
\hline $\begin{array}{l}\text { Work to Family } \\
\text { Conflict }\end{array}$ & 2 & $2-8$ & 0.84 & $\begin{array}{l}\text { [28] Frone, M., Russell, M., \& } \\
\text { Cooper, M. (1992) }\end{array}$ \\
\hline Family Focus $^{\text {b }}$ & 7 & $0-7$ & 0.67 & Developed for study \\
\hline
\end{tabular}

Table 2. Scale Descriptive Information. Note: All scales scored such that higher numbers reflect higher levels of the construct. a The health problems scale was modified to reflect the researchers' specific interest in stress-related health problems; ${ }^{b}$ Sample items of this subscale include: "Compared to the past, in the last two years, have you devoted more time to your family?" and "Compared to the past, in the last two years, have you become more focused on your work?" All questions were answered with a "yes" or "no." This scale is composed of seven items.

$\mathrm{p}<.05$, and (3) report higher levels of work to family conflict, $F(1,2187)=4.50, p<.05$. Women non-managers are most likely to have an employed spouse or partner, $F(1$, $1719)=25.17, p<.001$.

We next conducted independent samples T-tests to examine the differences between men managers and women managers on all variables. Significant effects were found for feeling overloaded at work, $\mathrm{t}(325)=-2.71, \mathrm{p}<.01$, reporting health problems, $\mathrm{t}(321)=-1.99, \mathrm{p}<.05$, and having an employed spouse or partner, $\mathrm{t}(287)=$ $3.79, p<.001$.

Although significant interaction effects and main effects were found, the proportion of total variance explained shows very small effect sizes across the board (less than $8 \%$ in all cases except spouse employment).

d. Effects of Marital Status and Children
Due to our failure to find more pronounced interaction effects, we explored the demographic variables of presence of children under 18 and marital status within each group to see if they could explain variations in the dependent measures. We investigated the difference in means of those with and without children among female non-managers, female managers, male non-managers and male managers using a $2 \times 2 \times 2$ ANOVA. The issue of children is worth examining due to the strain created by the increase in commitment of time and focus needed outside of the workplace (Pleck et al., 1980). Although we assumed that we would find a significant difference between female managers with children and without children on issues such as work to family conflict, stress and shift of life focus, the analysis failed to reveal any significant differences. 
Using 2x2x2 ANOVAs we next examined the interaction effects of gender, marital status and managerial status on our variables. Work to family conflict had a significant interaction $(F=4.86, p<.05)$, with single female managers reporting the highest levels of work to family conflict. No other significant interactions were found.

\section{DISCUSSION AND CONCLUSION}

The results of the survey indicate that female managers report work to family conflict at levels higher than male managers, female non-managers, and male nonmanagers, thus providing support for our hypothesis. However, the effect sizes are smaller than we anticipated, suggesting that the levels of work-family conflict reported by female managers is unexpectedly similar to the levels of work to family conflict reported by male managers. A managerial main effect for the variable of work to family conflict further indicates that managerial status is an important predictor of work to family conflict.

When men managers and women managers were compared on the variables of interest, significance was found only for work overload, health problems, and spouse employment. The lack of significant differences in these analyses between men managers and women managers on the work-family conflict variables does not support our hypothesis and further indicates that men managers and women managers are experiencing similar levels of workfamily conflict.

Although most health and coping and job attitudes indicators did not show a relationship with group differences in levels of work to family conflict as we predicted, significant interactions were found for problem drinking and work overload. Women managers' higher levels of problem drinking and work overload may be related to work-family conflict. Additionally, the managerial main effects for the job attitude variables of job stress, work overload, job involvement, and job challenge suggest that these job attitudes may be related to work to family conflict.

In examining effects of marital status and presence of children under 18 , our $2 \times 2 \times 2$ ANOVAs found that marital status has an effect on work to family conflict, with all other variables unaffected by marital status and children. In explaining the nonsignificant effects of marriage and the presence of children, it may be that our gender/managerial groups have enough explanatory value so as to make this further division ineffectual at finding differences. Additionally, caution should be taken in interpreting these analyses, as the group sizes were small $(\mathrm{N}=14$ for women unmarried managers) and the likelihood of error occurring was large due to the high number of analyses conducted.

Nonetheless, our $2 \times 2 \times 2$ analyses of marital status, gender, and managerial status was significant for work to family conflict, with single women managers reporting the highest levels of conflict. We investigated whether or not this finding was due to this group having substantially more children and found that the presence of children was similar between groups. Considering that the groups have similar amounts of children, our data suggest that the combination of being female, manager, and single is related to higher levels of work to family conflict. Again, this finding must be treated with caution, as the number of single managerial women in our sample is 14 .

Based on the small effect sizes of the interaction for work to family conflict, we cannot fully conclude that women managers' level of work family conflict is reflective of actual differences in women managers' experience. Indeed, the lack of more pronounced findings, in light of our literature supported hypothesis, leads us to consider why women managers report levels of work to family conflict similar to men managers, although we must refrain from concluding "no difference" on the basis of this finding alone.

One possible explanation for similar levels of work to family conflict for managers may be the entering or exiting of women from the workforce due to circumstances relating to the balance of work and family. For women more than men, the prospect of work-family conflict may discourage employment in general and may particularly be a deterrent to pursuing a managerial career. Those who do pursue a managerial career are likely to be the ones who are less conflicted by the demands of their work and family roles. The gender and managerial demographics of the company, as well as 
the health and coping, job attitude, and family issue variables of the gender managerial groups examined in this study, might be affected by this selective entering or exiting. Similar levels of work-family conflict reported by women managers and men managers may reflect the absence of those women who would be most likely to experience work-family conflict.

In addition to self-selection as an explanation for less pronounced effects, the coping abilities of women managers may be better than male managers; women managers may have more developed strategies for dealing with the conflicts of work and family roles than the men managers. Additionally, women managers may have accepted a certain level of workfamily conflict as part of their lives and thus do not notice and report it as much as the other groups.

While self-selection and coping skills of women managers may explain similarities in levels of work-family conflict between female and male managers, it is also possible that male managers are facing similar challenges as female managers in balancing work and family roles. Male managers may be increasingly identifying with their family role and experiencing the pressure to find a balance between work and family.

Similarities in work to family conflict between women and men managers may be interpreted as women managers having reached a level of equivalency with men managers. However, further study should explore whether preemptive consideration of the balance of work and family roles explains this similarity through self-selection. Examining women managers' experience with work-family conflict is crucial to understanding the unique challenges that may be facing women in positions of authority. Such examination is necessary if women are to overcome these challenges.

\section{REFERENCES}

1. U.S. Department of Labor, Bureau of Labor Statistics. (n.d.). Current Population Survey 2001, Employment Characteristics of Families, Table 5: Employment status of the population by sex, marital status, and presence and age of own children under 18, 2000-01 annual averages. Retrieved September 29, 2002, from http://stats.bls.gov/ news.release/famee.t05.htm.

2. Higgins, C. A. Duxbury, L. E. \& Irving R. H. (1992). Work-family conflict in the dual career family. Organizational Behavior and Human Decision Processes, 51, 51-75.

3. Pietromonaco, P.R., Manus, J., Frohardt-Lane, K. (1986). Psychological consequences of multiple social roles. Psychology of Women Quarterly, 10, 373-382.

4. Pleck, J. H., Staines, G. L., and Lang, L. (1980). Conflict between work and family life. Monthly Labor Review, 103(3), 29-32.

5. Kopelman, R.E., Greenhaus, J.H., \& Connolly, T.F. (1983). A model of work, family, and interrole conflict: A construct validation study. Organizational Behavior and Human Performance, 32, 198-215.

6. Greenhaus, J. H. \& Beutell, N. J. (1985). Sources of conflict between work and family roles. Academy of Management Review, 10(1), 76-88.

7. Kahn, R.L., Wolfe, D.M., Quinn, R., Snoek, J.D., \& Rosenthal, R.A (1964). Organizational stress. New York: Wiley.

8. Duxbury, L. Higgins, C. \& Lee, C. (1994). Work-family conflict: A comparison by gender, family type, and perceived control. Journal of Family Issues, 15, 449-466.

9. Gutek, B.A., Searly, S., \& Klepa, L. (1991). Rational versus gender role explanations for work-family conflict. Journal of Applied Psychology, 76, 560568.

10. Simon, R. W. (1995). Gender, multiple roles, role meaning, and mental health. Journal of Health and Social Behavior, $36,182-194$

11. Voydanoff, P. (1988). Work role characteristics, family structure demands, and work/family conflict. Journal of Marriage and the Family, 50, 749-761.

12. Yogev, S., \& Brett, J. (1985). Patterns of work and family involvement among single and dual earner couples. Journal of Applied Psychology, 70, 754-786.

13. Adams, G.A., King, L.A. \& King, D.W. (1996). Relationships of job and family 
involvement, family social support, and work-family conflict with job and life satisfaction. Journal of Applied Psychology, 81, 411-420.

14. Reskin, B. \& Ross, C.E. (1995). Jobs, authority and earning among managers: The continuing significance of sex. In J.A. Jacobs (Ed.), Gender Inequality at Work. Thousand Oaks, CA:Sage.

15. Wajcman, J. (1996). The domestic basis for the managerial career. The Sociological Review, 44, 609-629.

16. Davidson, M. \& Copper, G. (1992). Shattering the glass ceiling: The women manager. London: Paul Chapman.

17. Blair-Loy, M. (2001). Cultural constructions of family schemas: The case of women finance executives. Gender \& Society, 15(5), 687-709.

18. Hochschild, A, (with Machung, A.). (1989). The second shift. New York: Viking Press.

19. Frone, M.R., Russell, M. \& Barnes, G.M. (1996). Work-family conflict, gender, and health-related outcomes: A study of employed parents in two community samples. Journal of Occupational Health Psychology, 1, 57-69.

20. Thomas, L. T. \& Ganster, D.C. (1995). Impact of family-supportive work variables on work-family conflict and strain: A control perspective. Journal of Applied Psychology, 80, 6-15.

21. Smith, P.C., Balzar, W.K., Ironson, G.H., Paul, K. B., Hayes, B., Moore-Hirschl, S., \& Parra, L.F. (1992). The development and validation of the stress in general (SIG) scale. Paper presented at the Seventh Meeting of the Society for Industrial and Organizational Psychology, Montreal, Canada.

22. Cammann, C., Fichman, M., Jenkins, G.D., Jr., \& Klesh, J.R. (1983). Assessing the attitudes and perceptions of organizational members. In S.E. Seachore, E.E. Lawler, P.H. Mirvis, \& C. Cammann (Eds.), Assessing Organizational Change. New York: John Wiley and Sons.

23. Lodahl, T. \& Kejner, M. (1965). The definition and measure of job involvement. Journal of Applied Psychology, 71, 500-507.

24. Moos, R. H., Cronkite, R.C., Finney, J.W., \& Billings, A.G. (1986). Health and daily living form manual (Rev. ed.). Palo Alto, CA: Veterans Administration and Stanford University Medical Center.

25. Ewing, J.A. (1984). Detecting alcoholism. Journal of the American Medical Association, 252, 1905-1907.

26. Pearlin, L. I. \& Schooler, C. (1978). The structure of coping. Journal of Health and Social Behavior, 19, 2-21.

27. Amirkhan, J. H. (1990). A factor analytically derived measure of coping: The coping strategy indicator. Journal of Personality and Social Psychology, 59, 1066-1074.

28. Frone, M.R., Russell, M. \& Cooper, M.L. (1992). Antecedents and outcomes of work-family conflict: A model of the work-family interface. Journal of Applied Psychology, 77, 65-78.

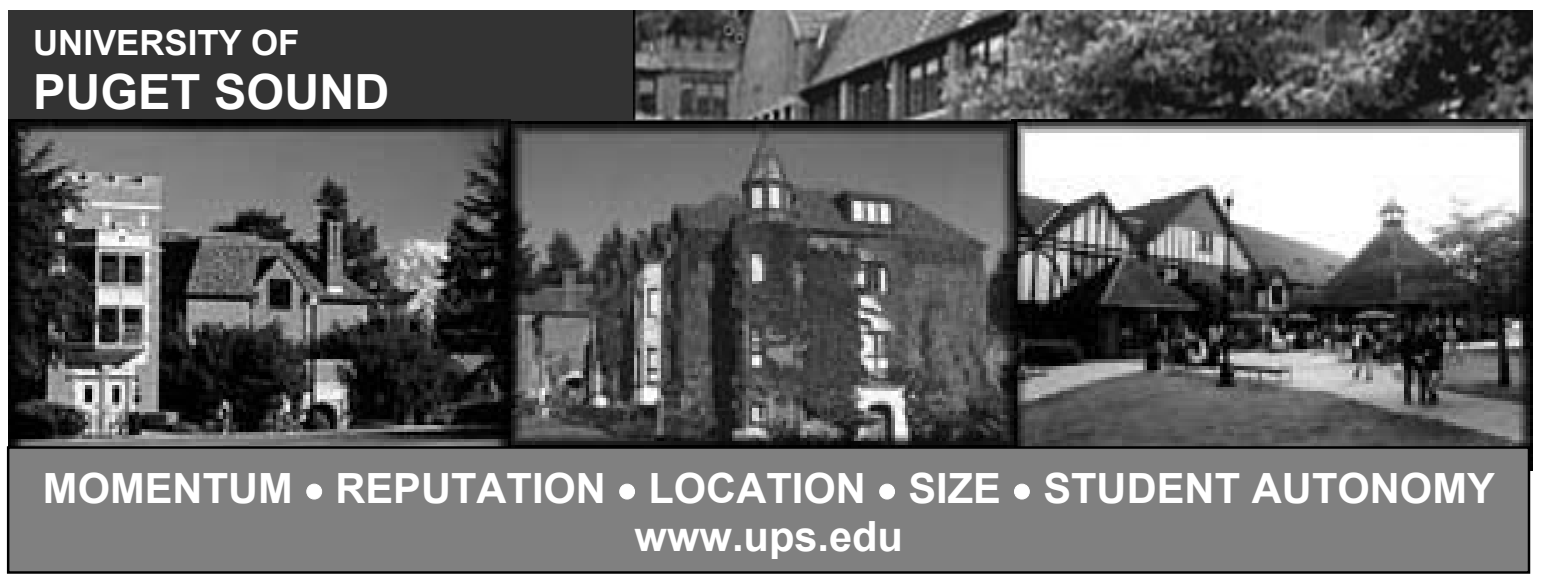



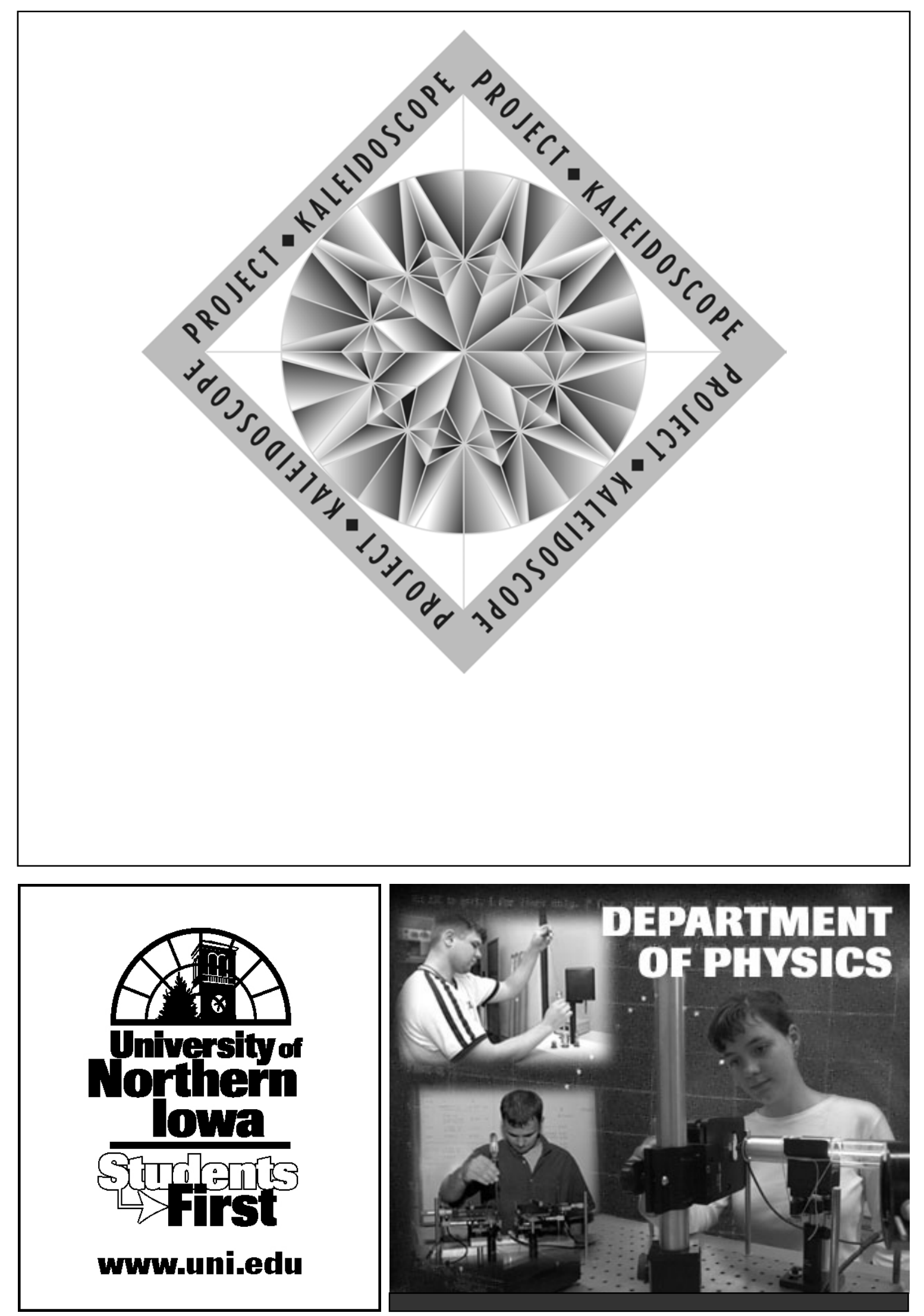